\title{
Allen Schnatberg.
}

Del exceso a la escasez

El libro de Schnaiberg representa probablemente la exposición más madura del análísis marxista (o neomarxista) de la "dialéctica sociedad medio ambiente». Es también, quizá, la contribución teórica más substancial a la sociología medioambiental hasta la fecha.

Esencialmente, este estudio tiene tres partes. En primer lugar, se plantea la cuestión de la relación recíproca entre la sociedad y el medio ambiente. Se comparan y contrastan la producción medioambiental y la producción económico-social y se descubren los vínculos entre ambas. En este contexto, Schnaiberg discute los problemas medioambientales de la producción económica Éste es, de hecho, el verdadero punto de partida de su análisis. El segundo tema es el análisis de los orígenes de «la desorganización de los ecosistemas". El tercer y último problema que se plantea es la reacción social al cambio nedioambiental.

Según Schnaiberg, lo que la sociedad produce en bienes se orienta hoy en día hacia el uso de producción excedente para crear un «capital de energía intensiva» que permitirá un mayot aumento de la producción. El modelo de crecimiento que se pone en marcha crea presiones y exigencias en el entorno biológico y físico (que es la fuente de la base material de la producción de la sociedad) y conduce a lo que denomina «desorganización de los ecosistemas». De aquí los «tiesgos sociales» implicados en la desorganización del ecosistema y que se clasifican en dos categorías principales: amenazas biológicas directas (carcinógenos y toxinas medio ambientales, tuptura de los eslabones alimentarios y cambio climatoló gico) y «amenazas de la producción socio-cultural» (que podrían consistir en el desempleo, reducción de ingresos, rentabilidad disminuida y dispo nibilidad disminuida de los servicios páblicos). Estas amenazas probablemente trastornatán finaimente la base material sobre la cual se mantienen 
las sociedades, con el consiguiente resultado de tal vez desastrosos tipos de cambios socio-políticos.

Schnaiberg se pregunta por qué ha seguido este curso el proceso productivo. $Y$ responde: \&La producción industrial ha cambiado debido a) al crecimiento de la población, b) a los imperativos tecnológicos, c) a los deseos de consumidores cada vez más desproporcionados y $d$ ) a los rasgos inherentes a la organización de los productores, especialmente de los productores capitalistas» (p. 43).

Aunque considere que el crecimiento demográfico de la población es un elemento importante que contribuye a la desorganización de los ecosistemas, el autor no adopta una postura malthusiana radical. Su posición, según él mismo dice, es la de un «moderado poblacionismo»: «El control de la población no es sino un elemento más que debe tenerse en cuenta para evitar la desorganización de los ecosistemas» (p. 61).

Si Schnaiberg se muestra cauteloso sobre el papel que juega la población en el incremento de problemas medioambientales, no demuestra tener las mismas reservas con el papel que juega la tecnología moderna. Demuestra que la "tecnología industrial de última hora», acarrea un alto riesgo medioambiental a causa de su carácter intensivo y esto es, como ya hemos mencionado, lo que parece yacer en el fondo de la cuestión de la desorganización de los ecosistemas.

La última sección del libro examina la teacción social ante el cambio medioambiental. Una de las contribuciones más significativas de este libro es el modo con que analiza las presiones políticas que determinan la na. turaleza de la investigación del impacto de la producción sobre el medio ambiente. En los EE.UU., la investigación está inevitablemente orientada hacia la producción y no a evaluar dicho impacto. No obstante, el moviwiento ecológico creció a partit de la conciencia de las secuelas medio ambientales, a pesar de los esfuerzos llevados a cabo para ocultar información y contener la investigación sobre el deterioto. Schnaiberg deja bien claro que el único camino a seguir es el de formar una coalición entre los obreros (sindicatos) y los ecologistas, que logre una redistribución equitativa del excedente, mientras que la producción en sí se adapta más a los condicionamientos ecológicos. En relación con los sistemas de producción ecológicamente aceptables, la «tecnología alternativas jugaría un papel principal.

«La rutina del capitalismo político no se construyó en una sola noche, como tampoco desaparecerá a corto plazo. Los esfuerzos mantenidos para despertar las conciencias, el afrontar el conflicto político y el desarrollo de una coordinación entre los ecologistas y los movimientos por la igual. dad social pueden servir para reducirlo a pedazos» (p. 440). 